\title{
STUDY OF DETERIORATION AND DEGRADATION OF OVERLAID WOODEN DOORS IN OTTOMAN CARAVANSARY IN BULAQ,CAIRO, EGYPT
}

\author{
Ali, N. \\ Conservation dept., Faculty of Archaeology, Fayoum University, Egypt \\ e-mail: nagla_egypt73@yahoo.com
}

\begin{abstract}
This paper presents an analytical study of the deterioration and degradation phenomena of two overlaid wooden doors from Ottoman period caravansaries: $(A)$ Hassan Pasha caravansary- $X$ century BC - XVI century AD and (B) Ibrahim Sarhan caravansary- X Century BC- XVI Century $A D$ in Bulaq, Cairo, Egypt. To identify the deterioration and degradation in the types of wood used, microbiological study, Scanning Electron Microscopy coupled with X-ray Energy Dispersive (SEM-EDX), X-ray Diffraction (XRD) were conducted. The data obtained were used to evaluate the status of conservation of overlaid wooden doors (wood and Iron) and to identify the suitable treatment methods.

parts.
\end{abstract}

Keywords: Wood, Iron, Overlaid, Corrosion, Salts, Biodeterioration, Biodegradation, XRD,

\section{Introduction}

The Turkish architecture is one of the most wonderful and special architecture in the World throughout the history [1]. Ottoman Period in Cairo was a great period for art and economic development [2]. The trade activity was in the forefront of this development, which extended also to new areas. Port Bulaq in Cairo was an important port on river Nile. The state of Bulaq has begun to shine after El-Fostat damage in the era of As-Sultān Parspai (825-842H.)-(14381421G.). Bulaq area has many Caravansaries, stores, khans and markets. (A) Hassan Pasha Al-wazir Caravansary No.538, fig. (1), is the most important one in this area. This Caravansary was founded in the XVI century. It is located at Sook-Al-Asr street, in El Sabtteya district. Dr. Nelly Hanna said; "Hassan Pasha began in building this Caravansary in $\mathrm{X}$ century, but he didn't finish it, because he left Egypt, and Sinan Pasha finished it" [3]. This Caravansary was dedicated for selling rice until the French campaign era. This Caravansary was completely demolished except for the main entrance. Pauty said; that "this Caravansary has been a very great building, of the same fashion of the Ottoman building in Turkey". At the present, no remains, of this Caravansary, have survived, except the main entrance which is decorated with a beautiful arch, which is decorated in turn, with letters gathered at the top of the arch in a circle, bearing two word inscription, (AllahAhad). Two columns, carved in the 
entrance walls, bearing the main arch. This entrance has an overlaid wooden door, with two leaves, of $320 \mathrm{~cm}$ in width, and $410 \mathrm{~cm}$ in height. each leaf includes 43 iron bands fixed together with iron nails. (B) Ibrahim Sarhan Caravansary construction No.43, fig. (2) is founded in Sook-Al-Asr street in Bulaq, to the right side going towards Sabtteya direction. This Caravansary lies in front of Hassan Pasha's one. It was built in the XVI century. This Caravansary was called a Caravansary of cheese. There are no remains left of this Caravansary except the ground floor and main entrance, which includes wooden door with two leaves, of $310 \mathrm{~cm}$ in width, and $410 \mathrm{~cm}$ in height [4], and each leaf has four iron bands as shown in figure 2 . This research focuses on the overlaid wooden doors, covered with iron, to save

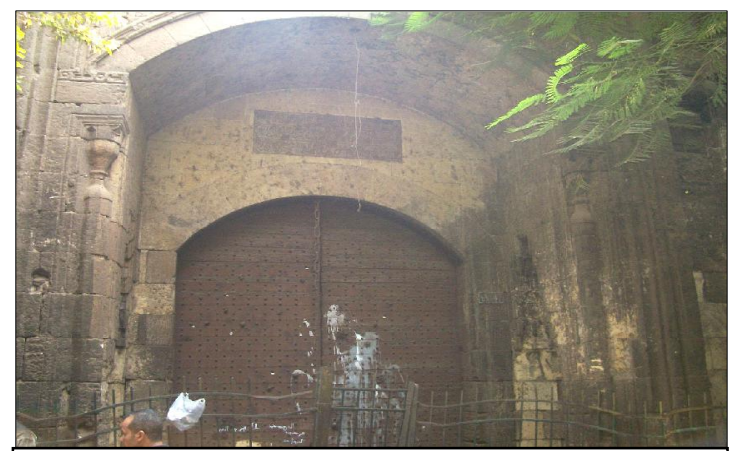

Figure (1) Overled wooden door of Hasssan pasha

\section{MATERIALS and METHODS}

Some wood and iron samples of Ottoman caravansaries in Bulaq taken from both overlaid doors were firstly described using optical microscope to

\subsection{Microscopes}

Some types of microscopes were used for investigating different surfaces and features of the monuments under study. optical microscope (OM) was used to identify the type of wood (essence), its conservation state at the micro-structural level and identify biodeterioration and biodegradation effects. Stereo optical

\subsection{X-ray analysis}

Spectroscopy electron dispersion X-ray (EDX), which can identify the elements of the corrosion products. Also, wood from weathering, leading to shrinkage and twist. The overlaid doors are made of wooden frame, and consist of wooden boards, fixed together, with iron nails [5], or bands fixed with tongue and groove joints without any iron nails [6], the craftsmen used finely metal bands formed and fixed on the wooden frame [7]. This research focuses on the deterioration and degradation phenomena of the overlaid Ottoman wooden doors. The investigation and analysis showed that overlaid doors suffer from a high percentage of salts and corrosion. This high percentage plays a serious role in swelling of wood fibers and chemical reaction between salts and iron. Also, the old wood suffers from diverse microorganisms (special kind of bacteria, fungi and levures) which can live in salted media.

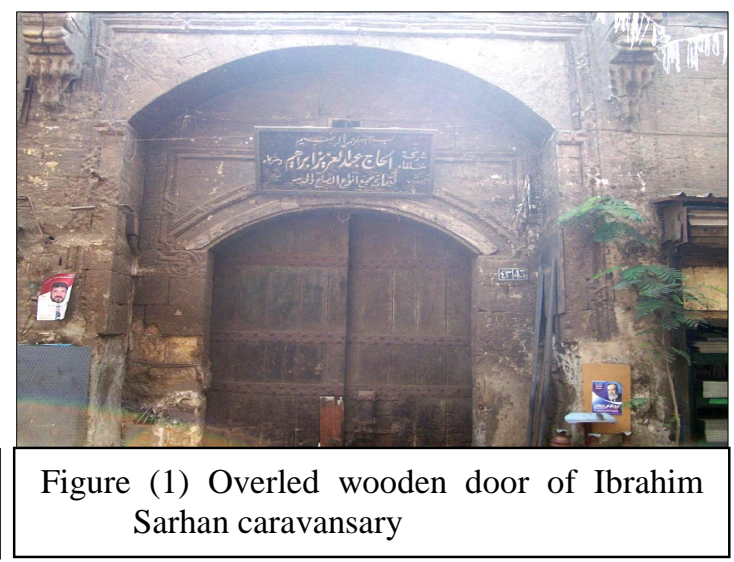

identify kind of wood and of forms of microbiological attacks. Then they were submitted for further investigations by some methods of follows:

microscope (SOM) was used to identify the corrosion layers in iron bands. Scanning electron microscope (SEM) was also used to examine the morphological features of the samples through using magnification ranges from $300 x$ up to $1,000,000 \mathrm{x}$ and more.

-X-ray Diffraction technique (XRD) was carried out to identify the crystalline materials in overlaid wooden doors. 


\section{RESULTS AND DISCUSSION}

\subsection{Samples of Hassan Pasha caravansary}

3.1.1. Naked eye examination

Naked eye examination highlighted many layers of iron corrosion, spots of salts and spots of

microorganisms as a result of high moisture in the door area, as shown in fig. (3) .
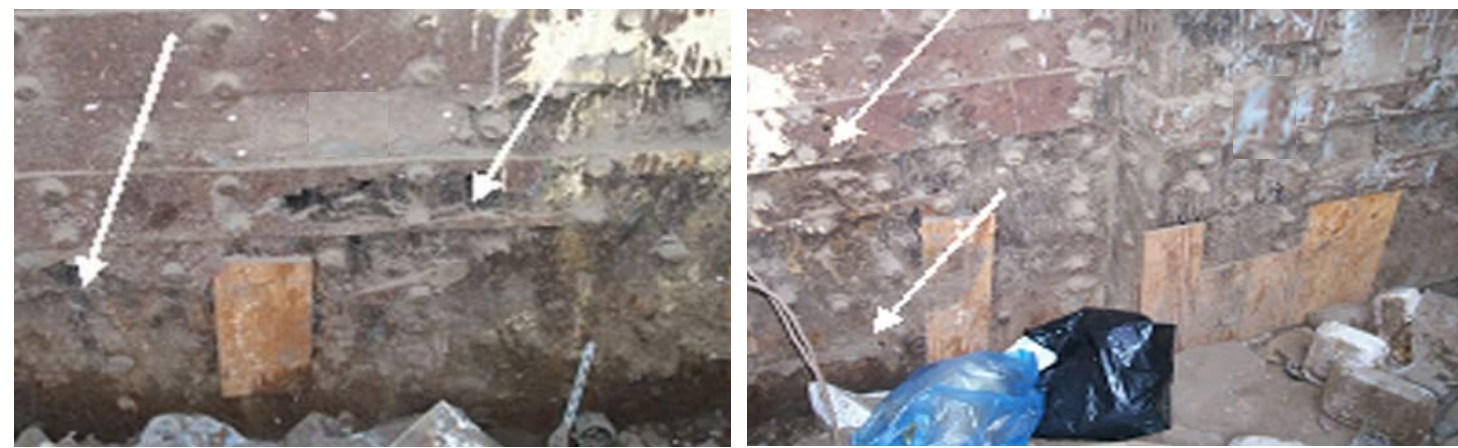

Figure (3) deterioration phenomena on Overlaid wooden door of Hassan Pasha caravansary

\subsubsection{Optical microscopy analysis}

The optical microscopy examination showed that the type of wood is pinus sylvestris [8] as shown in fig. (4). Also, optical microscopy, was used for microbiological activity examination, which was intense as a 3.1.3. Stereo-microscope

Stereo-microscope is the most useful means in showing the thickness of corrosion layers and the core metal as shown in fig. (6). This figure reflects

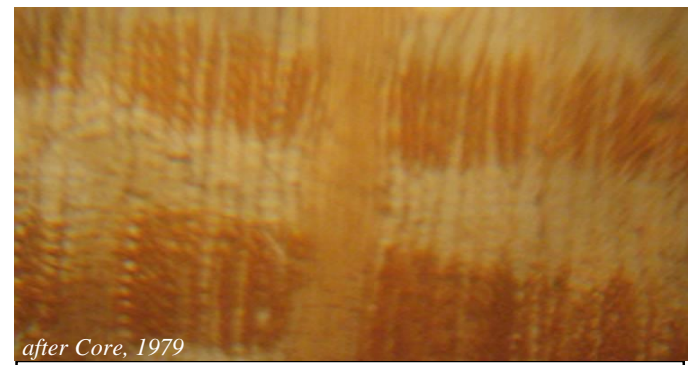

Figure (4) light microscope photo of (T.S) section confirming that the type of the wood is Pinus svlvestris result of high moisture content in wood and of the presence of alkaline elements like $\left(\mathrm{Na}^{+}, \mathrm{K}^{+}\right)$. Micro organism samples were taken to identify the type of species fig. (5).

the characterization of degradation products and the interaction of the object with the environment [9].

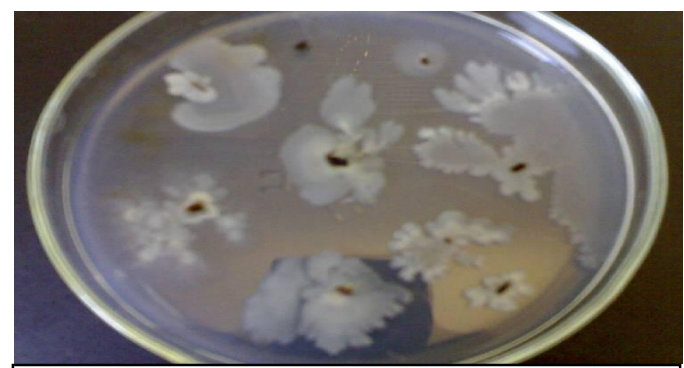

Figure (5) light microscope photo of bacteria infection Bacillus $S p$.

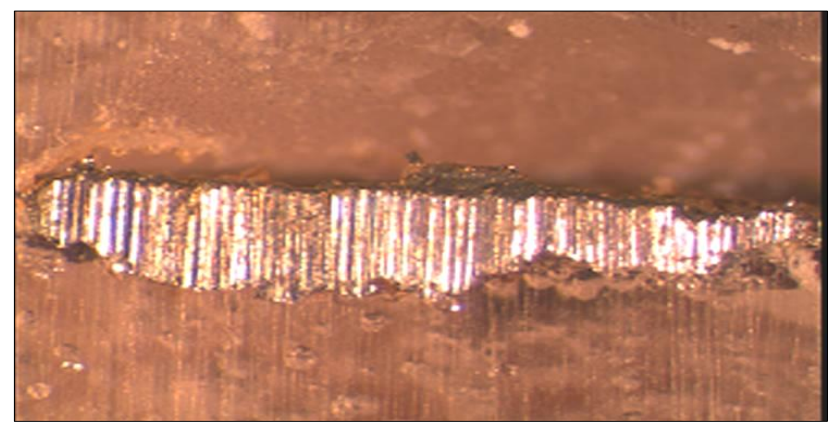

Figure (6) stereo-microscope photo the corrosion layers and the iron core of Hassan Pasha caravansary under. 


\subsubsection{SEM-EDX examination}

SEM-EDX examination showed

the presence of the clay, corrosion products and salts on iron bands surface in Hassan Pasha caravansary,

as listed in tab. (1) and shown in fig. (7). Also, SEM micro photos show the wood fibers, with salts in between its, fig. (8-a, b, c).

Table (1) \& Figure (7) EDX microanalysis of the iron bands in Hassan Pasha caravansary

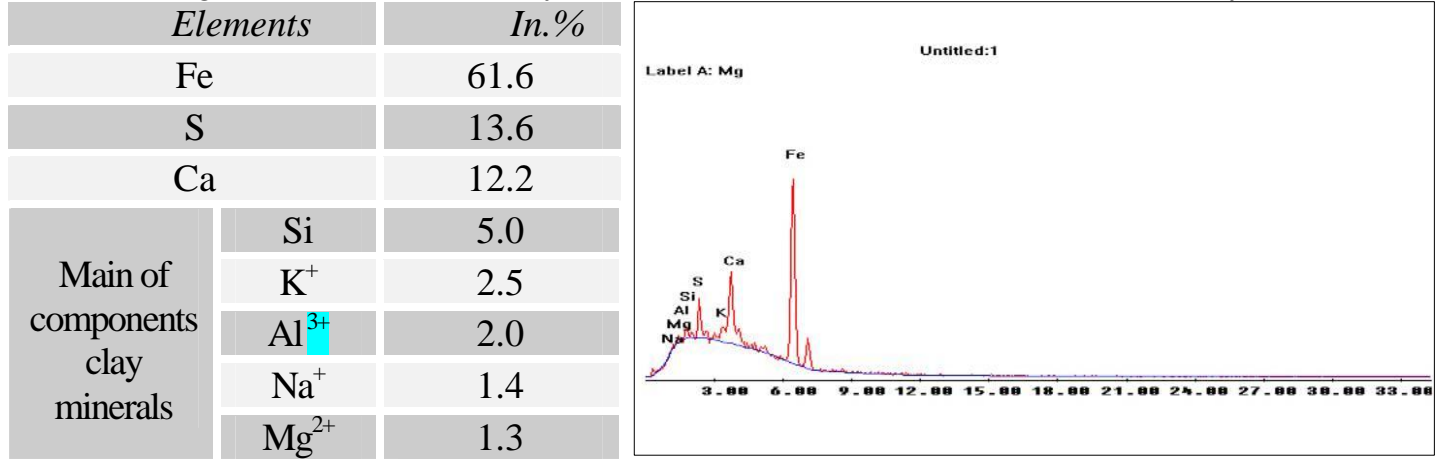
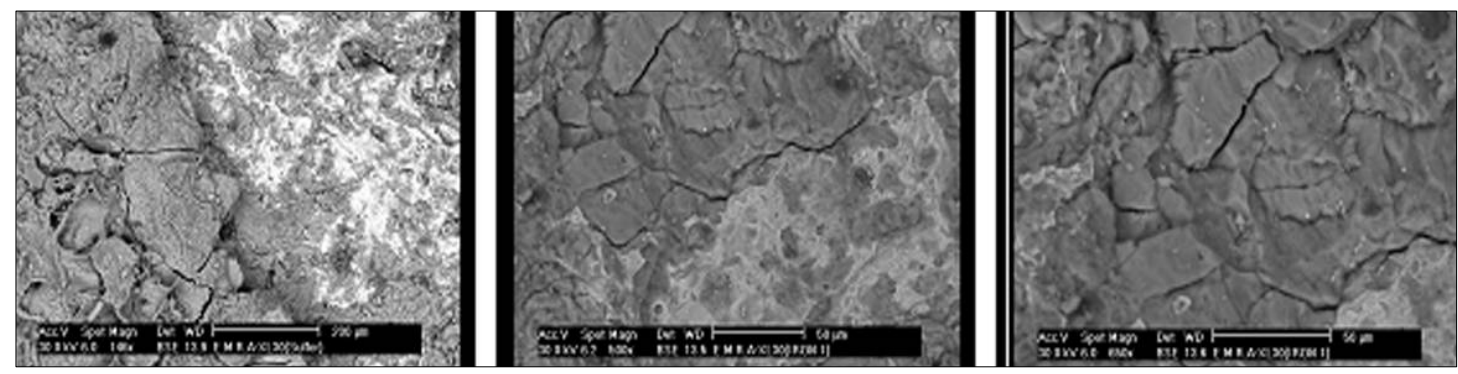

Figures (8) SEM micro-photographs of the studied samples taken from Hassan Paha caravansary a X-

$146, \underline{\mathbf{b}} \mathrm{X}-650 \underline{\mathbf{c}} \mathrm{X}-1500$ showing clay minerals, corrosion, and salts layers affected iron surface

\subsubsection{XRD examination}

XRD analysis of the Hassan Pasha overlaid wooden door iron bands fig. $(9$ \& 10) showed the presence of potassium and magnesium silicate $\left(\mathrm{K}_{2} \mathrm{Mg}_{5} \mathrm{Si}_{12} \mathrm{O}_{30}\right)$ card 10-0008, Hydromolysite $\left(\mathrm{FeCl}_{3} \cdot 6 \mathrm{H}_{2} \mathrm{O}\right)$, card (33-0645), Illite $\left(\mathrm{KAl}_{2} \mathrm{Si}_{3} \mathrm{AlO}_{10}(\mathrm{OH})_{2}\right)$, card $(02-0042)$ Calcite $\left(\mathrm{CaCO}_{3}\right)$, card (5-0586), Hematite $\left(\mathrm{Fe}_{2} \mathrm{O}_{3}\right)$ card (13-534) and Goethite $(\mathrm{FeO}$ $\mathrm{OH})$, card (17-0536). In addition XRD analysis of the salts present between wood fibers on overlaid wooden door of Hassan Pasha showed the presence of Aragonite $\left(\mathrm{CaCO}_{3}\right)$, card (0-1067),

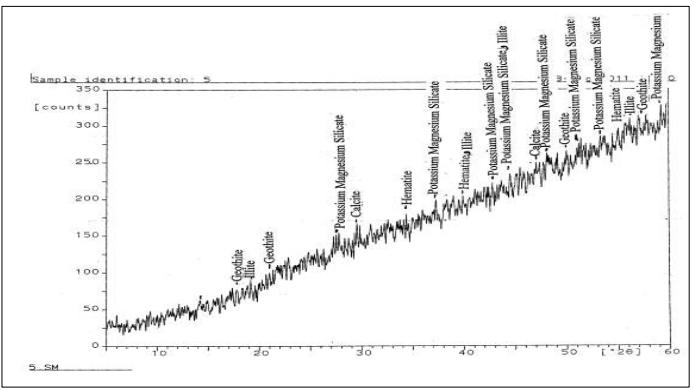

Figure (9) XRD paterns of the iron sample of Hassan Paha caravansary cellulose $\left(\mathrm{C}_{6} \mathrm{H}_{10} \mathrm{O}_{5}\right)$ n card (3-226), Halite $(\mathrm{NaCl})$ card (5-0628), Calcite $\left(\mathrm{CaCO}_{3}\right)$, card (5-0586), Quartz $\left(\mathrm{SiO}_{2}\right)$, card (50490), and Goethite (FeO OH), card (170536). From specialized point of view, it could be said that the presence of hydrated phases of clay minerals as illite and iron oxide type goethite, has a strong effect on the microstructural elements of the overlaid wooden door [10]. The presence of salts type Aragonite have the specific effect of the calcium carbonate at high temperature.

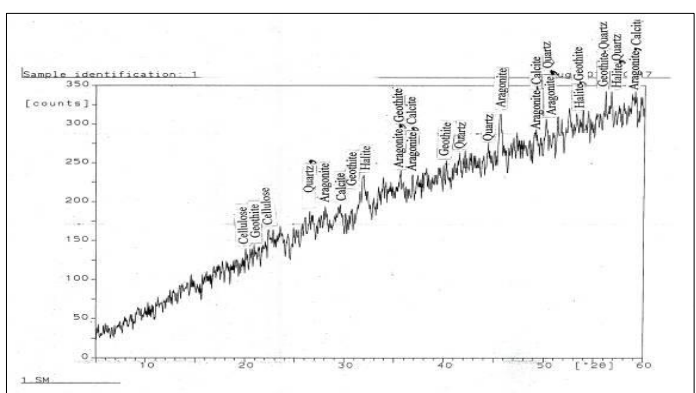

Figure (10) XRD paterns of the salts in the wood sample of Hassan Paha caravansary 


\subsection{Samples of Ibrahim Sarhan Caravansary}

\subsubsection{Naked eye examination}

Naked eye examination showed that there are many layers of iron corrosion, spots of salts and spots of biodeterioration and biodegradation as a result of high moisture in the door area, fig. (11). This high levels of humidity

and its changes may induce changes in size and shape causing internal stresses on overlaid wooden doors. High humidity can develop chemical reaction and create a favorable habitat for microbiological degradation [11].
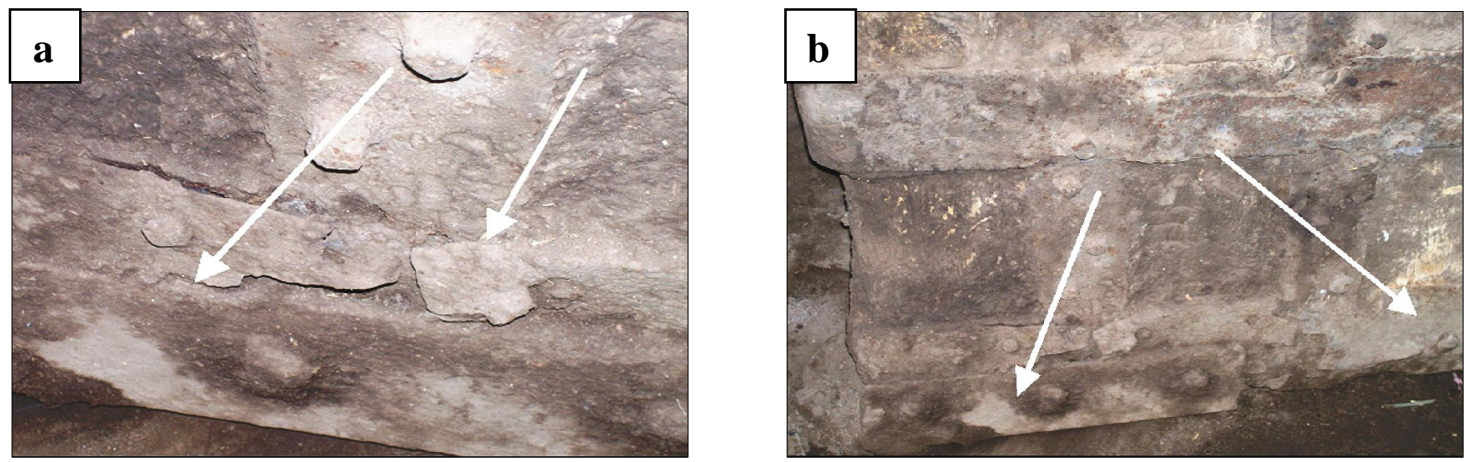

Figure $11(\mathrm{a}, \mathrm{b})$ deterioration phenomena on Overlaid wooden door of Ibrahim Sarhan caravansary

\subsubsection{Optical microscopy analysis}

With the optical microscope is studied the type of old wood, which is Pinus Nigra, fig. (12). Shows that the type of bacteria is Bacillus Sp. which

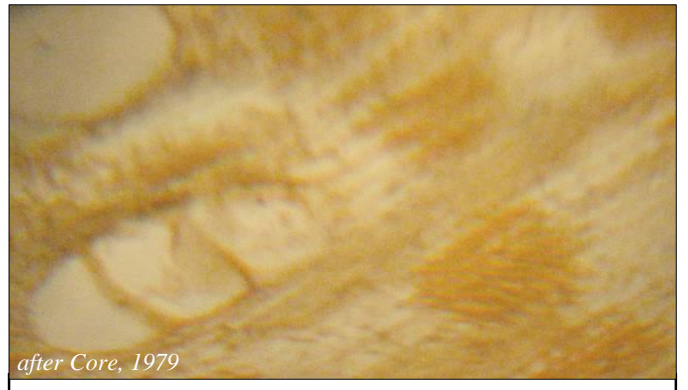

Figure (12) Fig. (12) OM photo of (T.S) section confirming that the type of the wood is Pinus nigra

\subsubsection{Stereo-microscope}

Stereo-microscope is the most useful way in showing the thickness of feeds on the bonding material between cellulose fibers, destroying the mechanical properties of wood, as shown in fig. (13).

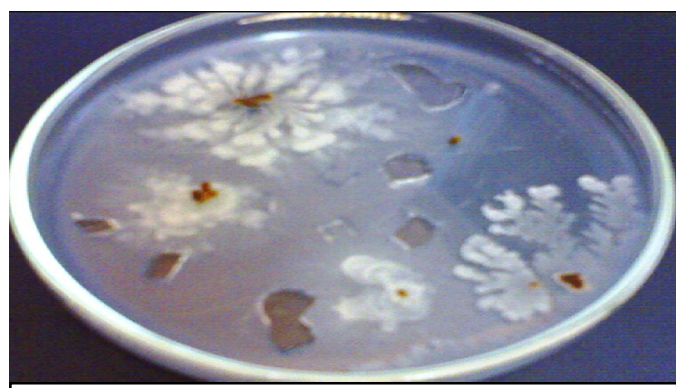

Figure (13) light microscope photo of bacteria infection Bacillus Sp. Said, M., Bacterial disease dept., Agricultural research center, 2011

corrosion layers and the core metal, as shown in fig. (14).

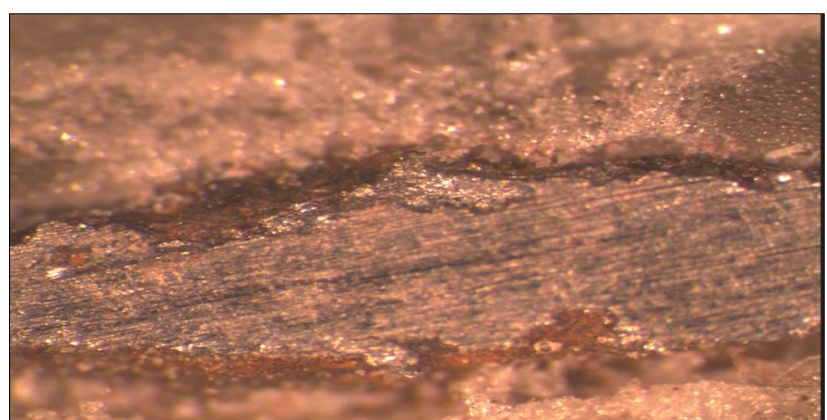

Figure (14) corrosion layers of Hassan Pasha caravansary under stereo-microscope. 


\subsubsection{SEM-EDX examination}

The results of microanalysis evaluated according to data listed in tab. (2) and EDX spectra, fig. (15) showed that iron $(\mathrm{Fe})$ is the main element and has a concentration of $51.7 \%$, sulfur (S) $18.3 \%$, calcium (Ca) $17.8 \%$, silicon $(\mathrm{Si}) 5.3 \%$ and the rest of the elements is the compensation of clay minerals. The SEM microphotographs

show the clay, corrosion and salts on iron surface, fig. (16), and salts between its fibers closing the wood pores. These photos present the damage occuring from many salts which crystallize between fibers, and compress the wood fibers under the iron band.

Table (2) \& Figure (15) EDX microanalysis of the iron bands of Ibrahim Pasha caravansary

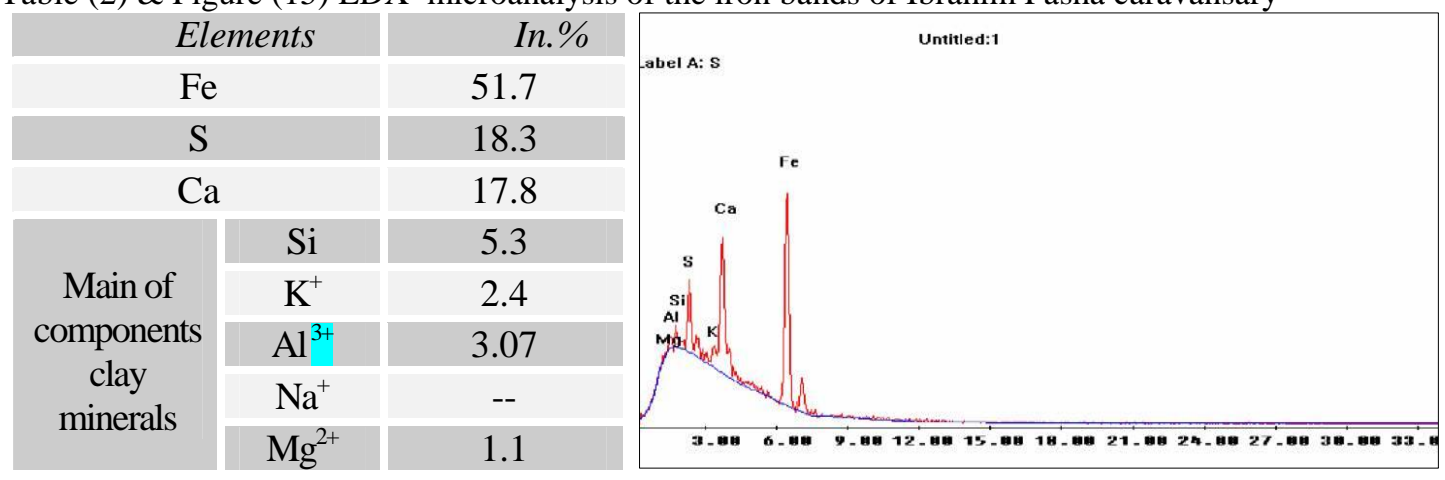
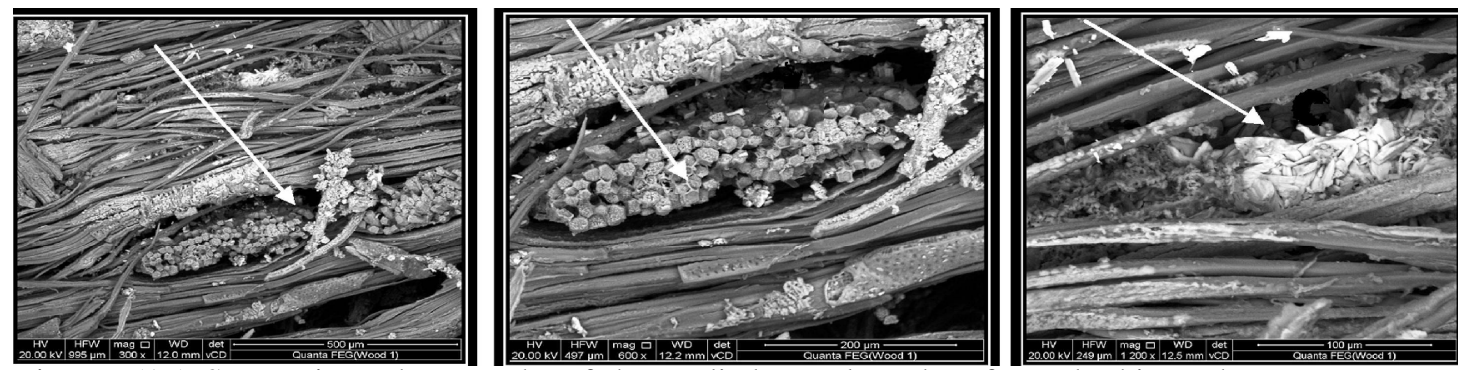

Figures (16) SEM micro-photographs of the studied samples taken from Ibrahim Paha caravansary a X-600, $\underline{\mathbf{b}}$ X-600 $\underline{\mathbf{c}}$ X-1200 showing clay minerals, corrosion, and salts layers affected iron surface

\subsubsection{XRD examination}

XRD analysis of the iron bands of Ibrahim Sarhan overlaid wooden door show the presence of Montmorillonite clay $\left(\mathrm{NaMgAlSiO}_{2}(\mathrm{OH}) \cdot \mathrm{H}_{2} \mathrm{O}\right)$ card $(02-$ 0014), Anhydrite $\left(\mathrm{CaSO}_{4}\right)$ card (60226), Gypsum $\left(\mathrm{CaSO}_{4} \cdot 2 \mathrm{H}_{2} \mathrm{O}\right)$ card (60046), Magnetite $\left(\mathrm{Fe}_{3} \mathrm{O}_{4}\right)$ card (110614), Hematite $\left(\mathrm{Fe}_{2} \mathrm{O}_{3}\right)$ card (13-534). On the other hand, the XRD analysis of the salts between wood fibers of overlaid door of Ibrahim Sarhan showed the presence of Halite $(\mathrm{NaCl})$ card (5-0628), cellulose $\left(\mathrm{C}_{6} \mathrm{H}_{10} \mathrm{O}_{5}\right)_{\mathrm{n}}$ card (3-226), Calcite $\left(\mathrm{CaCO}_{3}\right)$, Quartz $\left(\mathrm{SiO}_{2}\right)$ card (5-0490) and Aragonite $\left(\mathrm{CaCO}_{3}\right)$ and also the presence of hydrous phases of clay minerals, as
Montmorillonite, which present as a strong effect on the degradation of overlaid wooden door. Presences of Anhydrite declare the effect of high temperature on gypsum as shown in, fig. (17). The occurrence of salts as Halite, Aragonite and Calcite destroys the mechanical properties of wood, on the other hand, it could be said that the presence of Quartz, fig. (18) is as a knife which cuts in the wood fibers. Finally, it could be claimed that both objects suffer from severe deterioration forms resulted essentially from the aggressive effects of deterioration. These effects that need some conservation procedures to preserve them. 


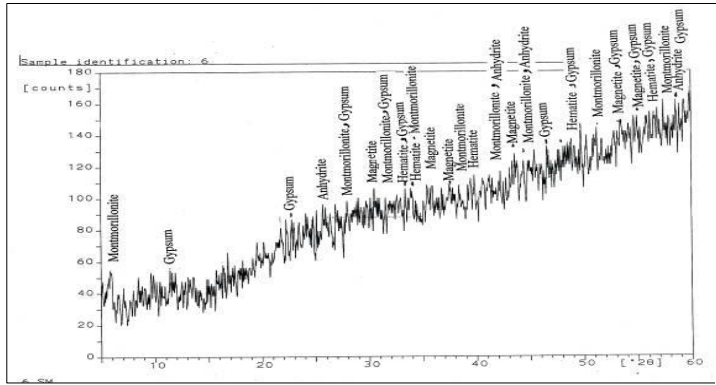

Figure (17) XRD paterns of the iron sample of Ibrahim Sarhan caravansary

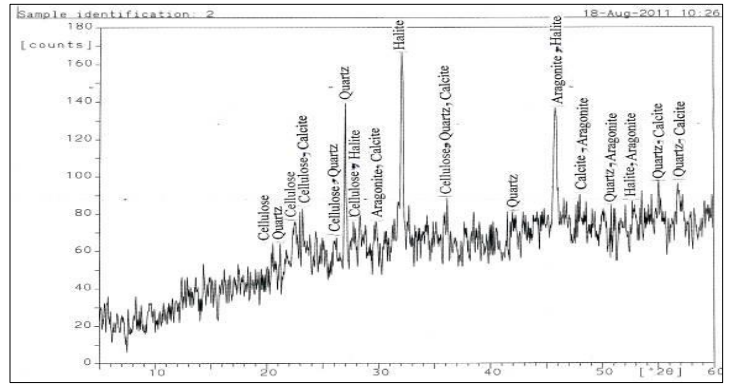

Figure (18) XRD paterns of the salt sin the wood sample of Ibrahim Sarhan caravansary

\section{CONCLUSIONS}

From the results obtained using several analytical techniques (optical microscopy, Stereo microscopy, SEM-EDX, XRD and microbiological analysis) of the overlaid wooden doors, the following information was deduced:

- The type of wood in (A) Hassan Pasha caravansary was Pinus sylvestris.

- The type of wood in (B) Ibrahim Sarhan caravansary was Pinus nigra.

- The type of biodegradation and biodeterioration in two caravansaries were Bacillus Sp.

- The overlaid bands have thick corrosion layers but still have a metal core.

- There are thick layers of clay minerals on overlaid wooden doors as a result of moisture content and dust deposited.

- There are many kinds of salts between wood fibers like Halite, Aragonite, Anhydrite, Gypsum) which damaged the wood fibers.

- The high levels of humidity and variability may induce changes in size and shape causing internal stresses on overlaid wooden doors;

- The high humidity develop chemical reaction and furnish a favorable habitat for growth of microbiological degradation and deterioration.

Finally, The results obtained will provide the conservators with essential information needed to select the most suitable materials and methods that can be used in conservation and restoration works.

Acknowledgement: The authors would like to thank Prof. Dr. Mohamed A. El-Gohary Prof. of Conservation of Stones and Archaeological Buildings, Manager of Archaeological and Conservation Studies and Research Center (ACSRC) \& Editor in Chief of Egyptian Journal of Archaeological and Restoration Studies (EJARS) Sohag Univ.-Egypt. Dr. Mohamed Sad, Lecture in Department of English faculty of literature, Fayoum University .

\section{References}

[1] Tanyeri-Erdemir, T. (2006). Archaeology as a source of national pride in the early years of the Turks, Field Archaeology, Vol. 31 (4) pp: 381-393

[2] Hanna, N. (1983). An urban history of Bulaq in the Mamluk and Ottoman periods, J. Institut Francais $d^{\prime}$ Archeology Orientale, Vol. XIX, Cairo, pp: 33-40

[3] Pauty, E. (1936). Architecture au Caire, depuis la conquete ottomane, $J$. Institut Francais d'Archeology Orientale, Vol. 29, Cairo, pp: 31-34

[4] Stanely, L. (1986). The art of the Saracens in Egypt, Chapman, London.
[5] Creswell, K. (1959). The Muslim architecture of Egypt, Part II, Oxford University, London.

[6] Hautecoeur, L. (1932). Les mosquées du Caire, Tome ,I, Emest Leroux, Paris.

[7] Hamza, M. (1992). Selected archaeological Texts, Islamic Department, Faculty of Archaeology, Cairo University, Egypt.

[8] Core, H. (1979). Wood structure and identification, $2^{\text {nd }}$ Ed., Syracuse Press, New York.

[9] Guidi, G, (2001). The (ENEA) Activities in the cultural heritage field, in: Euro-Mediterranean classes 
in new materials and technologies for the conservation and restoration of cultural heritage, consisting of natural fibrous polymer, (ed.) Guidi, G., Venice, pp: 1-8.

[10] Bakr, A. \& Brania, A. (2011). Analytical study of two wall paintings from Kom Ohiem excavation (El-Fayoum, Egypt). EJARS, Vol. 1 (1) pp: 49-59
[11] Camuffo, D. (2001). Temperature and Moisture as Decay Factors, in: Euro-Mediterranean classes in new materials and technologies for the conservation and restoration of cultural heritage, consisting of natural fibrous polymer, (ed.) Guidi, G., Venice, pp:1-6 